\title{
Do Religious Factors Impact Armed Conflict? Empirical Evidence From Sub-Saharan Africa
}

\author{
MATTHIAS BASEDAU, GEORG STRÜVER, AND \\ JOHANNES VÜLLERS
}

GIGA German Institute of Area and Global Studies, Hamburg, Germany

\section{TIM WEGENAST}

GIGA German Institute of Area and Global Studies, Hamburg; and Department of Political Science and Public Administration, University of Konstanz, Konstanz, Germany

\begin{abstract}
Theoretically, the "mobilization hypothesis" establishes a link between religion and conflict by arguing that particular religious structures are prone to mobilization; once politicized, escalation to violent conflict becomes more likely. Yet, despite the religious diversity in sub-Saharan Africa and the religious overtones in a number of African conflicts, this assumption has not yet been backed by systematic empirical research on the religion-conflict nexus in the region. The following questions thus remain: Do religious factors significantly impact the onset of (religious) armed conflict? If so, do they follow the logic of the mobilization hypothesis and, if so, in which way? To answer these questions, this article draws on a unique data inventory of all sub-Saharan countries for the period 1990-2008, particularly including data on mobilization-prone religious structures (e.g., demographic changes, parallel ethno-religious identities) as well as religious factors indicating actual politicization of religion (e.g., inter-religious tensions, religious discrimination, incitement by religious leaders). Logit regressions suggest that religion indeed plays a significant role in African armed conflicts. These findings are compatible with the mobilization
\end{abstract}

Matthias Basedau is a political scientist and a senior research fellow at the GIGA Institute of African Affairs, where he also heads Research Programme 2, "Violence and Security." Georg Strüver is a research fellow within the "Contested Leadership in International Relations: Power Politics in South America, South Asia and Sub-Saharan Africa" project, financed by the Volkswagen Foundation, at the GIGA German Institute of Global and Area Studies. Johannes Vüllers is a research fellow in the framework of the "Religion and Civil War: On the Ambivalence of Religious Factors in Sub-Saharan Africa" project, financed by the German Foundation for Peace Research (DSF), at the GIGA Institute of African Affairs. Tim Wegenast is a research fellow at the GIGA German Institute of Area and Global Studies in Hamburg and a lecturer at the University of Konstanz.

Research for this article was funded by the German Foundation for Peace Research in connection with the research project "Religion and Civil War: On the Ambivalence of Religious Factors in Sub-Saharan Africa." The authors are also indebted to Peter Körner and Jessica Haase for their indispensable support with coding, as well as to Håvard Hegre, Thomas Richter, and two anonymous reviewers for their useful comments. The usual caveat applies.

Address correspondence to Matthias Basedau, GIGA German Institute of Area and Global Studies, Neuer Jungfernstieg 21, Hamburg 20354, Germany. E-mail: basedau@gigahamburg.de 
hypothesis, and stress the impact of conflict-prone religious structures, and particularly, the fact that overlaps of religious and ethnic identities are conflictprone. Future research should investigate the religion-ethnicity-nexus in more detail.

Keywords armed conflict, mobilization, religion, sub-Saharan Africa

\section{Introduction}

Quantitative research has failed to find support for the significant causal influence of religious factors on the onset of armed conflict in Africa and elsewhere. ${ }^{1}$ Rough terrain, weak state capacity, and socioeconomic problems appear to be among the most important robustly significant variables. ${ }^{2}$

This comes as a surprise since in a number of African armed conflicts such as those in Ethiopia, Eritrea, Sudan, Somalia, and Uganda, religion obviously plays a role. Recent descriptive empirical studies estimate that the prevalence of religious conflict ${ }^{3}$ is at least equal to the worldwide average but probably much higher. ${ }^{4}$ Also, the religious demography in Africa is diverse, which is often considered a risk, and religion plays a more pronounced role than it does, for instance, in Western countries. ${ }^{5}$ Theoretically, a link between religious factors and conflict can be established by a "mobilization hypothesis": Certain religious structures such as parallel ethnic and religious identities or changing religious demographics are prone to mobilization in politics; once politicized, violent conflict becomes likelier. However, quantitative studies mostly limit analysis to simple demographic variables such as population shares and thus have failed to systematically test the theoretically identified causal mechanisms, particularly mobilization mechanisms. The following questions thus remain: Do religious factors significantly impact the onset of (religious) armed conflict in Africa? Do effects, if present, follow the logic of the mobilization hypothesis and, if so, in what ways?

This article tries to answer these questions by drawing on a unique data inventory of all sub-Saharan countries for the period 1990-2008 that includes new measurements on religious variables in armed conflict but in particular encompasses indicators of various mobilization-prone religious structures (e.g., religious demographic changes, parallel ethno-religious identities) as well as religious factors indicating actual mobilization of religion (e.g., quality of inter-religious relations, incitement by religious leaders).

The article proceeds as follows: First, we review the literature, discuss how religion and conflict might be linked theoretically and what empirical studies have found. Particularly, we show that research on the religion-conflict link suffers from a lack of adequate data. We then develop our hypotheses that mainly draw on the idea of "mobilization" of religion, present our database, and outline our empirical strategy. The following section presents the results of logit regressions on the religious determinants of onset of religious and "regular" armed conflicts and discusses their implications for the validity of the mobilization hypothesis. Results show that particularly the overlap of ethnic and religious identities increases the risk of (religious) conflict onset. The final section summarizes the findings and draws conclusions for future research as well as for conflict prevention and resolution.

\section{How Religion May Impact Armed Conflict}

Over the last decade, there has been growing interest in research on the religion-conflict link. ${ }^{6}$ Today, the "ambivalence of religion" has been widely accepted: Religion may not 
only incite violence but also contribute to peace. ${ }^{7}$ Ambivalence also refers to the scope of impact. Sometimes religion may count more, in other circumstances it may count less. Furthermore, it seems plausible that the ambivalence of religion depends on context. ${ }^{8}$ Under certain religious and non-religious conditions, religion spurs conflict or fosters peace - or differs in regards to how much religion counts. Finally, it appears useful to consider different religious dimensions. "Religion" is a complex phenomenon and difficult to define precisely. ${ }^{9}$ We do not intend to solve this problem once and for all; we believe that for analysis in Social Sciences it is useful to distinguish between different dimensions of religion. ${ }^{10}$ There are different ways to typologize these dimensions - or "factors," as we prefer to say-but we basically mean that religion is not, as often intuitively thought, solely about religious ideas (and the respective discourse). Other religious factors relevant for social science analysis include demographic structures of religion, religious organizations, and the related behavior of religious actors. In this paper we will mainly distinguish between religious demographic structures on the one hand and the actual politicization of religion on the other hand. While structures refer to certain constellations such as fractionalization and the like, actual politicization is indicated, for instance, by the quality of inter-religious relations as well as the behavior of religious actors.

Theoretically, a number of hypotheses connect religious factors or variables to conflict: First, from a socio-psychological point of view, diverse religious identities, similar to ethnic and other social identities, form a group identity and can result in escalating inter-group dynamics. Research demonstrates that people often privilege in-group members over out-group members. ${ }^{11}$ As a result, violent escalation becomes likelier.

Second, religious identities are special. They are connected to particular religious ideas. Such religious ideas are shared values and norms legitimized by a transcendental source, and therefore it might be argued that they are hardly subject to negotiation and compromise given their accepted supernatural origin. ${ }^{12}$ This can also entail a higher propensity for violent behavior by religious actors: religious extremists may demand that non-believers and adherents to different religious traditions have to be converted by force, and heretics may have to be punished. Conflicts over the role of religion in society or the state are likely to emerge between different religious groups, especially if the religion in question claims universal validity. Furthermore, combatants might be motivated through specific religious rewards for participation in acts of violence. ${ }^{13}$

Third, religion - or more precisely, religious factors-might be understood as a possible mobilization resource for and in conflicts. This idea is by no means incompatible with the former two ideas, but this theoretical branch stresses the role of leaders in the organization of collective action. ${ }^{14}$ In order to mobilize followers, leaders can choose from different identities, such as religious, ethnic, or other social identities. Sometimes, religion may be the most rational choice for them. ${ }^{15}$ For instance, politicization of religion might increase the risk of a violent escalation of a conflict, which is principally rooted in political or socioeconomic problems. ${ }^{16}$

\section{Empirical Findings Thus Far}

Empirically, the coexistence of various religious communities within a given society should increase the likelihood of conflict onset because of the aforementioned socio-psychological in- and out-group dynamics and/or principally incompatible religious ideas ${ }^{17}$ Studies find no empirical evidence for this assumption. ${ }^{18}$ Religious 
diversity as such is not significantly linked to a higher probability of (domestic) armed conflict. Furthermore, the studies show mixed or non-significant results for other religious demographic structures. The results are neither consistent for a strongly fractionalized religious structure, nor for a so-called polarized structure, in which two more-or-less large religious groups coexist. ${ }^{19}$ However, some studies find positive evidence that conflicts that are fought along religious boundaries may display a higher intensity and may endure longer than other conflicts that are not fought along such lines. ${ }^{20}$

The empirical findings on religion as a mobilization resource are inconsistent. For instance, there is little support for the claim that a higher politicization of religion automatically increases the (internal) conflict risk. Studies found a resurgence of religion in politics in the last few decades worldwide, but a corresponding increase in religious conflicts did not occur. ${ }^{21}$ Moreover, case studies show that religious overtones in armed conflict do not necessarily depend on religious politicization. Rather, elites must convince believers to engage in specific behavior. Furthermore, these studies point out the importance of - and the dependence upon-numerous (non-religious) factors in mobilization processes, such as the organizational structures of religious organizations and their dependence on state regulations. ${ }^{22}$ These recent approaches underscore the importance of looking not only at interfaith relations, but also at the relationship between the religious groups and the conflict parties.

Looking at the literature that specifically deals with Africa, we find that the majority of scholarly works on religion and conflict in sub-Saharan Africa are single case studies focusing on countries such as Nigeria, Sudan, or Somalia; comprehensive quantitative and comparative studies on religion and conflict are virtually non-existent. ${ }^{23}$ This comes as a surprise since religion has a high social relevance in Africa, this relevance having apparently increased in recent years. ${ }^{24}$ Also, the religious diversity, particularly the juxtaposition of Christians and Muslims in many African countries and the continent as a whole, is often considered a risk. Though recent systematic descriptive studies have found that in almost half of the 48 sub-Saharan countries religion and violence are substantially linked in one way or the other, ${ }^{25}$ large- $n$ studies on the causal religion-conflict link in Africa find no evidence for a significant influence of religious diversity. ${ }^{26}$ Instead, Collier and Hoeffler find that combined high ethno-linguistic fractionalization and religious fractionalization decrease the likelihood of civil war incidence in Africa. ${ }^{27}$ Haynes estimates that socioeconomic and political factors better explain civil war (onset) than do ethnic and religious fragmentation. ${ }^{28} \mathrm{~A}$ recent study finds initial support for the mobilization hypothesis. ${ }^{29}$ In particular, the overlap of religious and ethnic boundaries apparently makes armed conflict more likely. ${ }^{30}$

Summarizing the global and Africa-specific state of the art on the religionconflict link, at least two observations are striking: First, there is a contradiction between the findings of single case studies and the results of quantitative and cross-regional studies. While religion generally plays at best a minor role in armed conflict, religion evidently impacts armed conflict and its dynamics in particular countries such as Nigeria and Somalia where extremist religious groups fight government and peace-keepers. ${ }^{31}$ Second, and closely related, the data quality of most of the large- $n$ studies seems to be questionable: commonly, studies only measure the influence of religion with demographical constellations. Only a few studies go further and consider religious incompatibilities or general remands on religious symbols. 


\section{Hypotheses: The Mobilization of Religion in Conflict}

The following question remains: Under what circumstances will religious factors increase the risk of armed conflict onset? We believe that the theoretical approaches discussed above are far from mutually exclusive but rather form different parts of what one might call the "mobilization hypothesis." ${ }^{32}$ In a nutshell, our "mobilization hypothesis" argues that religious phenomena will be rational sources for religious and/or political actors in conflict processes, if (a) particular conflict-prone religious structures are present and (b) religion also becomes politicized. These two conditions taken together are necessary to the mobilization of religion and, if jointly present, will increase the risk of (religious) armed conflict onset.

Both "structures" and "politicization" deserve brief illustration: In reference to the above-discussed theoretical approaches, specific religious demographic structures such as fractionalization, polarization, or the dominance of one religious group can be considered potentially conflict-prone ${ }^{33}$ Furthermore, some argue that parallel ethnoreligious identity structures are most conflict-prone because mobilization resources multiply in this context ${ }^{34}$ and in many African countries such as Côte d'Ivoire, Ethiopia, Nigeria, or Sudan ethnic differences often run parallel to a Christian-Muslim divide. Other authors will stress significant changes in the religious demographic structure. These changes render violence likelier because the religious group that is shrinking can feel threatened in their social position by the religious group that is growing. ${ }^{35}$

As argued above, religion must be politicized to be socially relevant for the believers and to be part of the conflict. Obviously, the behavior of leaders comes into play here. Incitements to violence by religious (and political) leaders increase the likelihood of conflict onset. Other proxies for religious politicization are feelings of discrimination on the part of religious groups and possibly already-existing inter-religious tensions. The quality of inter-religious relations may indicate the already-existing level of politicization or, more precisely, the perceptions of different religious communities vis-à-vis each other. "Tense" inter-religious relations, for example, indicate that socio-psychological in- and out-group dynamics have already materialized in the sense that they already matter for political conflict. ${ }^{36}$ Feelings of discrimination on the part of religious groups form another proxy for the salience of religious identities. Comparable to ethnic discrimination, religious discrimination can increase the likelihood of the onset of violent conflict. ${ }^{37}$

Taking into account this outline of the "mobilization hypothesis" our first hypothesis reads as follows:

H1: The onset of armed conflict is significantly connected to religious factors only when mobilization-prone religious structures in a given country are combined with evidence of politicization of religion.

Additionally, we argue that mobilization works better with regard to the type of conflict. Conflict-prone religious structures and politicization of religion should matter more for conflicts in which religion obviously plays a role, such as armed conflicts in which conflict parties differ by religious affiliations and/or religious incompatibilities are present. ${ }^{38}$ Accordingly, the second hypothesis reads as follows:

H2: The impact of the "mobilization mechanism" is substantially stronger for the onset of religious armed conflict than for "general" armed conflict. 


\section{Data and Empirical Strategy}

Given that many of the theoretically important religious factors have not been tested thus far, a new database on Religion in Sub-Saharan Africa (RSSA) is particularly useful for the purpose of this contribution. This database contains some 30 religion-specific variables, of which many are particularly important with regard to the testing of the mobilization hypothesis (see below).

The database covers the years 1990 to 2008 and includes all 48 countries of sub-Saharan Africa. Data were coded by year and we have a maximum of 909 observations per variable. ${ }^{39}$ Usually, variables were constructed either dichotomously or on nominal or ordinal scales. We were keen to maintain a uniform, consistent basis of sources in order to avoid distorted information. We used various annual Africa Yearbook editions, Religious Freedom Reports and Human Rights Practices Country Reports (the latter two compiled by the U.S. Department of State) as well as Economist Intelligence Unit Country Reports published on (at least) a quarterly basis.

In order to test whether religious indicators have an impact on internal violence propensity, we employed two different dependent variables. The variable conflict onset (Hypothesis 1) was taken from the UCDP/PRIO Armed Conflict Onset Dataset (version 4/2010) to measure intra-state conflict onset. The dichotomous variable conflict onset has a value of 1 if there is a conflict onset with more than 25 annual battle-related deaths. ${ }^{40} \mathrm{~A}$ total of 57 civil war events happened within the period under consideration (1990-2008) ${ }^{41}$ In order to capture religious armed conflicts (Hypothesis 2), we employed another dichotomous dependent variable (religious conflict onset) that takes the value of 1 if at least one intra-state conflict onset happened in which the warring factions differed substantially according to their religious affiliation. The variable encompasses a total of 26 onset-years in episodes in 13 different countries. In order to capture the ideological dimension of religious conflicts - as the second form of religious armed conflict according to our definition (see endnote 3) - we created a further variable for religious conflicts (religious conflict onset 2) that encompasses armed conflicts with a religious incompatibility. However, there are only 12 cases in seven countries rendering analysis less fruitful (see Table A3 in the Annex).

The explanatory variables included in this study describe the structural and politicized dimensions of the mobilization hypothesis. Regarding the religious structure, we include two continuous variables: First, we use the fractionalization index by Alesina et al. to measure religious heterogeneity (fractionalization). ${ }^{42}$ Second, we construct a polarization index of the inter-religious structure (Christians, Muslims, African Traditionalists) according to Montalvo/Reynal-Querol ranging from 0 to 1 (polarization) ${ }^{43}$ In addition, we included several binary variables from the RSSA database in the regression tables. We coded whether religious identities overlap at least partially with ethnic, regional, or social boundaries (religious-ethnic overlap, religious-regional overlap, religious-social overlap). ${ }^{44}$ Additionally, we coded three variables on religious dominance taking the value of 1 if at least $60 \%$ of a country's population adheres to Islam (dominance Islam), Christianity (dominance Christ), or if either Christians or Muslims form more than $60 \%$ of the population (dominance) ${ }^{45}$ Finally, we assessed if moderate or strong changes in the religious demography of a country occurred during the sample period (demographic change).

With regard to the politicized dimension of religion, we draw almost exclusively on new data collected in the RSSA database. Whether the inter-religious relations 
are contentious is considered by including the variable tensions. It is coded 1 if moderate or strong tensions exist in the relations between adherents of different religions in a country, and 0 otherwise. The binary variable discrimination measures whether a religious community feels discriminated against or not. In contrast, the variable minority discrimination does not measure the self-perception of a religious community but whether a minority religion is discriminated against objectively by government restrictions and laws. The variable draws on the categorical variable $m$ of the Religion and State Data. ${ }^{46}$ Further dichotomous variables quantify escalations by religious actors or institutions (e.g., legitimization or incitement of violence) (religious calls for violence), and the legitimization of violence by violent actors referring to religion (calls for violence).

Finally, we measured the combined effect of structural and politicized conditions by creating variables which take the value of 1 if both the structural and politicized dimensions are given. For instance, the variable dominance \& discrimination takes the value of 1 for societies in which the share of Muslims or Christians is greater than or equal to $60 \%$ (dominance) and a religious community feels discriminated against. $^{47}$

Control variables were chosen in accordance with sensitivity and meta-analyses performed by Hegre/Sambanis and Dixon. ${ }^{48}$ Given that our sample is restricted to relatively few cases (48 countries) and a short period of time (19 years), we decided to limit our base model to a total of seven control variables: ${ }^{49}$ logarithm of total population (log population), GDP growth (gdp growth), logarithm of per capita GDP (log $g d p p c$ ) (all from the World Bank African Development Indicators), regime durability (durable) measuring the years since the most recent regime change, the level of democracy (polity2) measured by the combined polity score (both from the Polity IV Project), ${ }^{50}$ as well as rough terrain (Imtnest_i) ${ }^{51}$ In addition, a variable reflecting the duration since the last event/onset (peace years) was included in all models in order to minimize problems of temporal dependence on a history of conflict. ${ }^{52}$ Except for peace years, all other independent variables were lagged one year. ${ }^{53}$

\section{Quantitative Findings}

Table 1 presents the results of the logistic estimations for variables on the religious structure and both dependent variables. ${ }^{54}$ In line with our expectations, we find that an overlap of religious identities with ethnic boundaries exhibits an increased conflict probability (Models 3 and 7 of Table 1). Parallel religious and ethnic boundaries such as in Sudan, Côte d'Ivoire, or Nigeria increase the odds for the onset of armed conflict and religious conflict by approximately 2 and 11 times, respectively. This may be due to the fact that out-group differences become more salient and are more easily exploited. ${ }^{55}$

We further find that predominantly Muslim societies are more likely to experience armed conflicts but not religious armed conflict (Models 4 and 8 of Table 1). Expressed in odds ratio, the dominance of Islam in a country doubles the risk of armed conflict onset. Albeit statistically not significant, countries with a Christian dominance also bear an 18\% higher risk of armed conflict onset. Only a high percentage share of adherents of ATR seems to reduce armed conflict risks slightly.

Our analysis also shows that religiously fractionalized and polarized countries seem to be less prone to armed conflict (Models 1 and 2 of Table 1). In addition, religious fractionalization also reduces the risk for religious conflict onset (Model 
Table 1. Conflict onset and religious structure

\begin{tabular}{|c|c|c|c|c|c|c|c|c|}
\hline & $\begin{array}{l}(1) \\
\text { Conflict } \\
\text { onset }\end{array}$ & $\begin{array}{l}\text { (2) } \\
\text { Conflict } \\
\text { onset }\end{array}$ & $\begin{array}{l}\text { (3) } \\
\text { Conflict } \\
\text { onset }\end{array}$ & $\begin{array}{l}\text { (4) } \\
\text { Conflict } \\
\text { onset }\end{array}$ & $\begin{array}{c}\text { (5) } \\
\text { Religious } \\
\text { conflict onset }\end{array}$ & $\begin{array}{c}\text { (6) } \\
\text { Religious } \\
\text { conflict onset }\end{array}$ & $\begin{array}{c}\text { (7) } \\
\text { Religious } \\
\text { conflict onset }\end{array}$ & $\begin{array}{c}(8) \\
\text { Religious } \\
\text { conflict onset }\end{array}$ \\
\hline L1.fractionalization & $-2.037^{\times \times *}(0.751)$ & & & & $-1.747^{*}(1.034)$ & & & \\
\hline $\begin{array}{l}\text { L1.polarization } \\
\text { L1.religious-ethnic } \\
\text { overlap }\end{array}$ & & $-1.776^{* \times *}(0.567)$ & $0.633^{*}(0.338)$ & & & $-0.493(0.8$ & $2.412^{* * * *}(0.704)$ & \\
\hline L1.dominance islam & & & & $0.737^{* *}(0.346)$ & & & & $0.397(0.485)$ \\
\hline L1.log population & $0.231(0.144)$ & $.164(0.131)$ & $0.0543(0.130)$ & $0.122(0.126)$ & $0.297(0.207)$ & $0.222(0.185)$ & $0.0227(0.248)$ & $0.207(0.181)$ \\
\hline L1.gdp growth & $0.0191(0.0142)$ & $0.0255^{*}(0.0146)$ & $0.0169(0.0130)$ & $0.0208(0.0142)$ & $0.0204^{*}(0.0115)$ & $0.0218^{*}(0.0118)$ & $0.0122(0.0106)$ & $0.0210^{*}(0.0114)$ \\
\hline L1.log gdppc & $-0.172(0.221)$ & $-0.383^{* *}(0.184)$ & $-0.322^{*}(0.195)$ & $-0.266(0.214)$ & $-0.0879(0.246)$ & $-0.240(0.215)$ & $-0.271(0.271)$ & $-0.192(0.235)$ \\
\hline L1.durable & $-0.0299^{*}(0.0174)$ & $-0.0169(0.0163)$ & $-0.0184(0.0174)$ & $-0.0256(0.0169)$ & $-0.0557^{* *}(0.0240)$ & $-0.0454^{*}(0.0272)$ & $-0.0411(0.0295)$ & $-0.0495^{* *}(0.0245)$ \\
\hline L1.polity2 & $0.0134(0.0276)$ & $0.0179(0.0291)$ & $0.0370(0.0302)$ & $0.0164(0.0269)$ & $0.0148(0.0355)$ & $0.0219(0.0381)$ & $0.0638(0.0426)$ & $0.0199(0.0358)$ \\
\hline L1.Imtnest_i & $0.148(0.104)$ & $0.0416(0.101)$ & $0.133(0.114)$ & $0.153(0.105)$ & $0.0736(0.147)$ & $0.0108(0.154)$ & $0.190(0.225)$ & $0.0529(0.144)$ \\
\hline peace years & $-0.102^{\times \times x}(0.0328)$ & $-0.0998^{x \times x}(0.0328)$ & $-0.109^{* * *}(0.0352)$ & $-0.109^{* * *}(0.0340)$ & $-0.121^{* *}(0.0483)$ & $-0.126^{* *}(0.0512)$ & $-0.0805^{\times}(0.0488)$ & $-0.125^{* x}(0.0509)$ \\
\hline _cons & $-3.783(2.701)$ & $-1.454(2.555)$ & $-1.579(2.200)$ & $-2.757(2.497)$ & $-5.692^{*}(3.416)$ & $-4.186(3.076)$ & $-3.547(3.155)$ & $-4.669(3.146)$ \\
\hline$N$ & 750 & 750 & 750 & 750 & 750 & 750 & 750 & 750 \\
\hline pseudo $R^{2}$ & 0.085 & 0.094 & 0.076 & 0.077 & 0.087 & 0.078 & 0.144 & 0.078 \\
\hline
\end{tabular}

Robust standard errors in parentheses, ${ }^{*} p<.10,{ }^{* *} p<.05,{ }^{* * *} p<.01,{ }^{* * * *} p<.001$.

Source: authors' compilation. 
5 of Table 1). These results partly corroborate previous authors advocating the conflict-reducing effect of fractionalization and polarization. Esteban and Ray, for example, suggest that (ethnic) polarization has a pacifying effect due to the large costs incurred whenever equally powerful groups face each other. ${ }^{56}$ Horowitz noted that the risk of internal violence decreases in highly homogeneous and highly heterogeneous societies, suggesting that a polarized structure is most conflict-prone. ${ }^{57}$ Collier and Hoeffler, and Ellingsen corroborate this claim by showing that countries with a moderate amount of ethnic fractionalization are more likely to experience civil war outbreak. ${ }^{58}$ Our findings on religious structures and conflict, however, are rather in line with Collier and Hoeffler's (2004) suggestion that it is neither fractionalization nor polarization but the contested dominance of one group (Muslims and, to some extent, Christians) that represents the highest armed conflict risk. ${ }^{59}$

The remaining, non-religious control variables are largely in line with the findings of previous studies. ${ }^{60}$ While a rough terrain (Imtnest_i) and a large population (log population) increase the risk of conflict onset, stable and peaceful regimes (durable, peace years) and economically rich countries in per capita terms $(\log g d p p c)$ are less likely to experience the onset of armed conflict. Note, however, that only regime stability and per capita income reach statistical significance at conventional levels. The coefficient's sign for the growth of national income ( $g$ dp growth) and regime type (polity2) seems to contradict some previous studies. This may be due to the restriction on a sample of sub-Saharan countries and a relatively short sample period compared to other quantitative civil war studies.

Next, we included variables indicating actual politicization of religion in the base model (Table 2). We asked, for example, whether countries characterized by contentious inter-religious relations run a higher risk of armed conflict. In general, the included variables do not reach statistical significance. ${ }^{61}$ The only exception is tensions; the presence of inter-religious relations characterized by moderate or severe tensions entails a higher armed conflict risk (Model 1 of Table 2). Odds ratios reveal that quarrelsome inter-religious relations make internal violence 2.6 times more likely.

In the next two tables (Tables 3 and 4), we return to our main hypotheses. We expect that the onset of armed conflict is significantly connected to religion only when the proper religious structures (e.g., high religious polarization or dominance, overlap of religious identities with ethnic boundaries) in a given country are combined with evidence of politicization. In order to test this proposition, we combined the polarization indices of inter-religious structure and dominance of Islam or Christianity (as well as the coexistence of religious and ethnic boundaries) with two "politicized" variables (discrimination, tensions). For this purpose, we created dummy variables (equaling 1) if, for example, a society is characterized by religious dominance (or religious polarization, coexistence of religious and ethnic boundaries) and - at the same time - one group experiences subjective feelings of discrimination (or inter-religious relations are characterized by anywhere from minor to severe tensions).

Contrary to our expectations, a combined effect of polarization - in this case, the fourth quartile (polarization75) - and religious discrimination (polarization75 \& discrimination) as well as contentious inter-religious relations and religious discrimination (polarization75 \& tensions) on armed conflict cannot be observed (Models 2 and 4 of Table 3). However, in religiously highly polarized societies, the risk of religious conflict onset is significantly increased if religious communities feel 
Table 2. Conflict onset and politicized religion

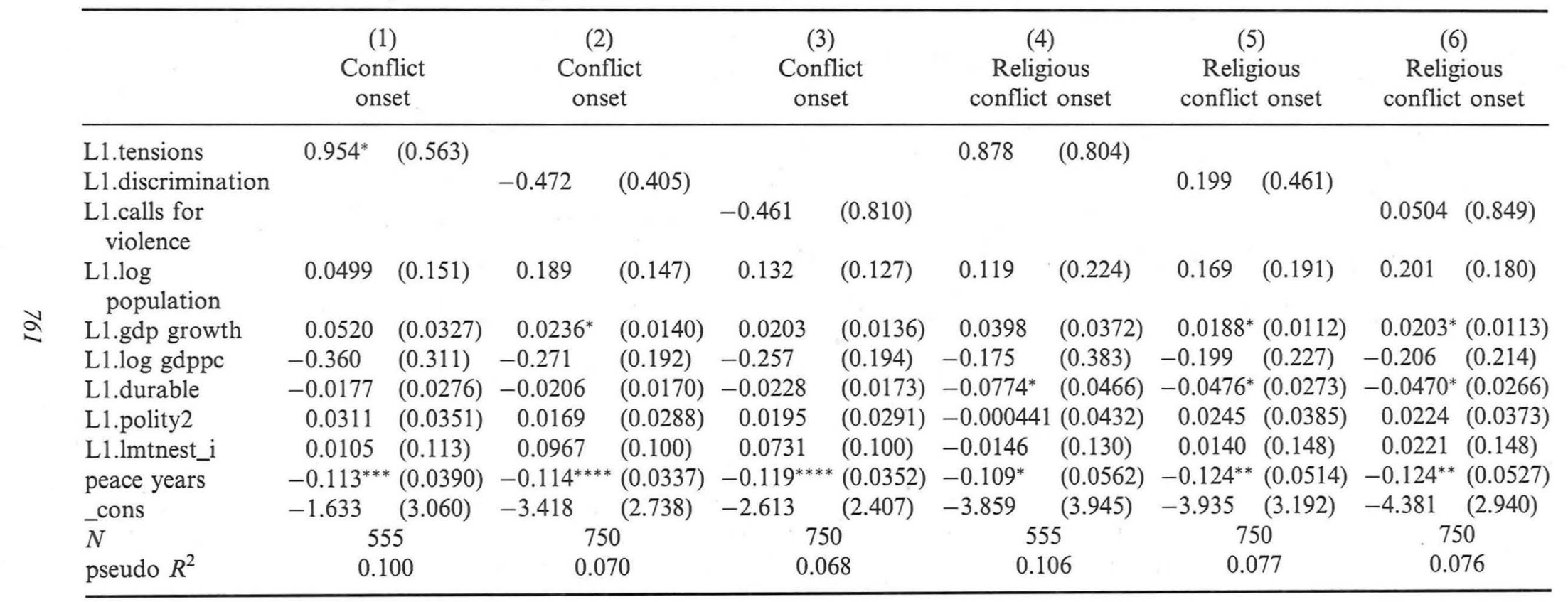

Robust standard errors in parentheses; ${ }^{*} p<.10,{ }^{* *} p<.05,{ }^{* * *} p<.01,{ }^{* * * *} p<.001$.

Source: authors' compilation. 
Table 3. Combined effects of the religious structure and politicized religion (1)

\begin{tabular}{|c|c|c|c|c|c|c|c|c|}
\hline & $\begin{array}{c}\text { (1) } \\
\text { Conflict } \\
\text { onset }\end{array}$ & $\begin{array}{c}\text { (2) } \\
\text { Conflict } \\
\text { onset }\end{array}$ & $\begin{array}{c}\text { (3) } \\
\text { Conflict } \\
\text { onset }\end{array}$ & $\begin{array}{l}\text { (4) } \\
\text { Conflict } \\
\text { onset }\end{array}$ & $\begin{array}{c}\text { (5) } \\
\text { Religious } \\
\text { conflict onset }\end{array}$ & $\begin{array}{c}(6) \\
\text { Religious } \\
\text { conflict onset }\end{array}$ & $\begin{array}{c}\text { (7) } \\
\text { Religious } \\
\text { conflict onset }\end{array}$ & $\begin{array}{c}(8) \\
\text { Religious } \\
\text { conflict onset }\end{array}$ \\
\hline L1.polarization 75 & $-0.491(0.347)$ & & $-0.663^{*}(0.398)$ & & $0.151(0.440)$ & & $0.597(0.535)$ & \\
\hline L1.discrimination & $-0.308(0.386)$ & & & & $0.151(0.425)$ & & & \\
\hline $\begin{array}{l}\text { L1.polarization75 } \\
\text { \& } \\
\text { discrimination }\end{array}$ & & $-0.0639(0.447)$ & & & & $0.964^{*}(0.512)$ & & \\
\hline L1.tensions & & & $1.005^{*}(0.547)$ & & & & $0.897(0.845)$ & \\
\hline $\begin{array}{l}\text { L1. polarization } 75 \\
\text { \& tensions }\end{array}$ & & & & $-0.2981(0.4248)$ & & & & $1.0564^{* *}(0.5342)$ \\
\hline $\begin{array}{l}\text { L1.log } \\
\text { population }\end{array}$ & $0.178(0.150)$ & $0.118(0.133)$ & $0.0942(0.166)$ & $0.1261(0.1632)$ & $0.168(0.191)$ & $0.0689(0.171)$ & $0.0682(0.217)$ & $0.0452(0.2084)$ \\
\hline L1.gdp growth & $0.0247^{*}(0.0145)$ & $0.0204(0.0139)$ & $0.0567^{*}(0.0330)$ & $0.0514(0.0336)$ & $0.0184^{*}(0.0111)$ & $0.0138(0.0109)$ & $0.0363(0.0347)$ & $0.0343(0.0344)$ \\
\hline L1.log gdppc & $-0.340^{*}(0.199)$ & $-0.281(0.197)$ & $-0.408(0.297)$ & $-0.4088(0.3266)$ & $-0.171(0.236)$ & $-0.119(0.220)$ & $-0.0747(0.417)$ & $-0.0444(0.4466)$ \\
\hline L1.durable & $-0.0177(0.0169)$ & $-0.0211(0.0177)$ & $-0.0110(0.0283)$ & $-0.0208(0.0284)$ & $-0.0491^{*}(0.0296)$ & $-0.0522^{*}(0.0282)$ & $-0.0857^{*}(0.0499)$ & $-0.0924^{*}(0.0509)$ \\
\hline L1.polity2 & $0.0221(0.0295)$ & $0.0229(0.0286)$ & $0.0358(0.0357)$ & $0.0283(0.0366)$ & $0.0215(0.0417)$ & $0.0166(0.0403)$ & $-0.00858(0.0489)$ & $-0.0168(0.0499)$ \\
\hline L1.Imtnest_i & $0.0758(0.104)$ & $0.0814(0.100)$ & $0.00767(0.115)$ & $0.0659(0.1086)$ & $0.0208(0.156)$ & $0.0194(0.151)$ & $-0.00164(0.135)$ & $0.0106(0.1318)$ \\
\hline peace years & $-0.112^{* * * *}(0.0333)$ & $-0.119^{* * * *}(0.0358)$ & $-0.115^{* * *}(0.0384)$ & $-0.126^{* * *}(0.0389)$ & $-0.122^{* *}(0.0529)$ & $-0.104^{*}(0.0552)$ & $-0.0963(0.0608)$ & $-0.0896^{* *}(0.0600)$ \\
\hline _cons & $-2.739(2.849)$ & $-2.292(2.449)$ & $-1.936(3.292)$ & $-1.7316(3.4105)$ & $-4.148(3.102)$ & $-3.031(2.730)$ & $-3.960(3.611)$ & $-3.2056(3.4760)$ \\
\hline$N$ & 750 & 750 & 555 & 555 & 750 & 750 & 555 & 750 \\
\hline pseudo $R^{2}$ & 0.076 & 0.067 & 0.111 & 0.0901 & 0.077 & 0.091 & 0.114 & 0.120 \\
\hline
\end{tabular}

Robust standard errors in parentheses; ${ }^{*} p<.10,{ }^{* *} p<.05,{ }^{* * *} p<.01,{ }^{* * * *} p<.001$.

Source: authors' compilation. 
Table 4. Combined effects of religious structure and politicized religion (2)

\begin{tabular}{|c|c|c|c|c|c|c|c|c|}
\hline & $\begin{array}{c}\text { (1) } \\
\text { Conflict } \\
\text { onset }\end{array}$ & $\begin{array}{c}\text { (2) } \\
\text { Conflict } \\
\text { onset }\end{array}$ & $\begin{array}{l}\text { (3) } \\
\text { Conflict } \\
\text { onset }\end{array}$ & $\begin{array}{l}\text { (4) } \\
\text { Conflict } \\
\text { onset }\end{array}$ & $\begin{array}{c}(5) \\
\text { Religious } \\
\text { conflict onset }\end{array}$ & $\begin{array}{c}\text { (6) } \\
\text { Religious } \\
\text { conflict onset }\end{array}$ & $\begin{array}{c}\text { (7) } \\
\text { Religious } \\
\text { conflict onset }\end{array}$ & $\begin{array}{c}(8) \\
\text { Religious } \\
\text { conflict onset }\end{array}$ \\
\hline L1.dominance & $0.611^{*}(0.322)$ & & $0.881^{* *}(0.379)$ & & $0.0486(0.428)$ & & $-0.309(0.537)$ & \\
\hline L1.discrimination & $-0.270(0.391)$ & & & & $0.213(0.436)$ & & & \\
\hline $\begin{array}{l}\text { L1.dominance \& } \\
\text { discrimination }\end{array}$ & & $-0.787(0.656)$ & & & & $-1.286(1.057)$ & & \\
\hline L1.tensions & & & $1.152^{* *}(0.555)$ & & & & $0.831(0.795)$ & \\
\hline $\begin{array}{l}\text { L1.dominance \& } \\
\text { tensions }\end{array}$ & & & & $0.927^{* *}(0.380)$ & & & & $-0.285(0.540)$ \\
\hline $\begin{array}{l}\text { L1.log } \\
\text { population }\end{array}$ & $0.183(0.149)$ & $0.139(0.123)$ & $0.106(0.163)$ & $0.134(0.160)$ & $0.170(0.193)$ & $0.242(0.171)$ & $0.0926(0.227)$ & $0.141(0.221)$ \\
\hline L1.gdp growth & $0.0249^{*}(0.0145)$ & $0.0202(0.0134)$ & $0.0636^{*}(0.0357)$ & $0.0614^{*}(0.0357)$ & $0.0189^{*}(0.0113)$ & $0.0207^{*}(0.0112)$ & $0.0371(0.0360)$ & $0.0362(0.0373)$ \\
\hline L1.log gdppc & $-0.366^{*}(0.196)$ & $-0.241(0.192)$ & $-0.471^{*}(0.285)$ & $-0.453(0.287)$ & $-0.209(0.231)$ & $-0.150(0.213)$ & $-0.103(0.411)$ & $-0.149(0.409)$ \\
\hline L1.durable & $-0.0195(0.0165)$ & $-0.0238(0.0173)$ & $-0.0121(0.0262)$ & $-0.0127(0.0270)$ & $-0.0473^{*}(0.0281)$ & $-0.0509^{*}(0.0271)$ & $-0.0812(0.0503)$ & $-0.0850^{*}(0.0479)$ \\
\hline L1.polity2 & $0.0169(0.0287)$ & $0.0132(0.0301)$ & $0.0258(0.0332)$ & $0.0257(0.0351)$ & $0.0249(0.0395)$ & $0.00563(0.0399)$ & $-0.00124(0.0451)$ & $-0.00670(0.0447)$ \\
\hline L1.Imtnest_i & $0.0646(0.105)$ & $0.0940(0.0993)$ & $-0.0269(0.123)$ & $0.00774(0.120)$ & $0.0113(0.159)$ & $0.0422(0.145)$ & $0.00625(0.148)$ & $0.0527(0.140)$ \\
\hline peace years & $-0.109^{* * * *}(0.0331)$ & $-0.109^{* * *}(0.0339)$ & $-0.111^{* * *}(0.0375)$ & $-0.119^{* * *}(0.0364)$ & $-0.125^{* *}(0.0522)$ & $-0.112^{* *}(0.0532)$ & $-0.103^{*}(0.0596)$ & $-0.112^{* *}(0.0544)$ \\
\hline _cons & $-3.212(2.852)$ & $-2.834(2.415)$ & $-2.605(3.256)$ & $-2.114(3.341)$ & $-3.918(3.172)$ & $-5.345^{*}(3.009)$ & $-3.712(3.813)$ & $-3.601(4.115)$ \\
\hline$N$ & 750 & 750 & 555 & 555 & 750 & 750 & 555 & 555 \\
\hline pseudo $R^{2}$ & 0.079 & 0.071 & 0.120 & 0.111 & 0.077 & 0.085 & 0.107 & 0.098 \\
\hline
\end{tabular}

Robust standard errors in parentheses; ${ }^{*} p<.10,{ }^{* *} p<.05,{ }^{* * *} p<.01,{ }^{* * * *} p<.001$.

Source: authors' compilation. 
discriminated against or the inter-religious relations are burdened with tensions (Models 6 and 8 of Table 3). Expressed probabilistically, the presence of polarization with discrimination and contentious inter-religious relations increase the odds for religious conflicts by approximately 2.6 and 2.4 times, respectively (see also Table 6).

With respect to religious dominance, Table 4 evinces that religious dominance exacerbates the risk for armed conflicts when there are simultaneous contentious inter-religious relations (dominance \& tensions) as shown by Model 4. Note, however, that a possible conditional effect of polarization and contentious inter-religious relations on armed conflict is rather weak, as the effect size of tensions by itself is higher than that of dominance \& tensions.

Finally, Table 5 summarizes the findings for the combined effects of parallel religious and ethnic boundaries and religious discrimination or contentious inter-religious relations. As can be observed, especially the coexistence of parallel ethno-religious boundaries with contentious inter-religious relations seems to have a strong positive and highly significant effect on religious conflict onset (Model 8). When African societies are characterized by overlaps of ethnic and religious boundaries as well as the presence of inter-religious tensions such as in Ethiopia or Côte d'Ivoire, the potential for religious conflicts increases by more than 9 times. A similar combined effect for contentious inter-religious relations and religious discrimination cannot be found. ${ }^{62}$

\section{Discussion}

The empirical data provide an answer to our key research question on whether religious factors impact the likelihood of armed conflict onset in Africa: As the previous section as well as the summary of results in Table 6 demonstrate, indeed, they do. Although religious variables certainly do not provide an exhaustive explanation of armed conflict in Africa, ${ }^{63}$ some variables such as overlapping ethnic and religious identities apparently exert substantial impact. "Overlaps" and other variables (such as inter-religious tensions and perceived discrimination) have been tested for the very first time, which may explain why many previous studies have not found significant impact of religious factors in Africa.

With regard to our two hypotheses, inspired by the idea of a "mobilization hypothesis," we find that Hypothesis 1 must be modified. Hypothesis 1 assumed that religious factors are connected to armed conflict only when structural and politicization variables interact. However, it is not exclusively this interaction that returns the best results. While politicization variables-indicators that capture feelings of discrimination and actual behavior of religious and violent actors - almost never independently impact armed conflict onset (exception: inter-religious tensions), structures characterized by an overlap of religious and ethnic boundaries-which is the strongest and most significant single variable (see Table 6) —or the dominance of one religious group (Islam) are independently significant variables. Combined variables - such as overlaps of polarization and identity under the condition of discrimination or tensions-also count. Except for the combined effect of polarization with tensions and discrimination, there is little evidence that the combined variables are much stronger than the effects of particular structural variables alone.

Regarding Hypothesis 2-the differences between armed conflict and religious armed conflict - results are not completely in line with our expectations either. Generally, religious factors do not have stronger influence on religious conflict than on 
Table 5. Combined effects of religious structure and politicized religion (3)

\begin{tabular}{|c|c|c|c|c|c|c|c|c|}
\hline & $\begin{array}{l}\text { (1) } \\
\text { Conflict } \\
\text { onset }\end{array}$ & $\begin{array}{l}\text { (2) } \\
\text { Conflict } \\
\text { onset }\end{array}$ & $\begin{array}{l}\text { (3) } \\
\text { Conflict } \\
\text { onset }\end{array}$ & $\begin{array}{l}\text { (4) } \\
\text { Conflict } \\
\text { onset }\end{array}$ & $\begin{array}{c}(5) \\
\text { Religious } \\
\text { conflict onset }\end{array}$ & $\begin{array}{c}(6) \\
\text { Religious } \\
\text { conflict onset }\end{array}$ & $\begin{array}{c}(7) \\
\text { Religious } \\
\text { conflict onset }\end{array}$ & $\begin{array}{c}(8) \\
\text { Religious } \\
\text { conflict onset }\end{array}$ \\
\hline $\begin{array}{l}\text { L1.religious-ethnic } \\
\text { overlap }\end{array}$ & $0.941^{* * *}(0.330)$ & & $0.511(0.432)$ & & $2.569^{* * * *}(0.666)$ & & $3.139^{* * *}(1.197)$ & \\
\hline L1.discrimination & $-0.909^{* *}(0.431)$ & & & & $-0.516(0.577)$ & & & \\
\hline $\begin{array}{l}\text { L1.overlap \& } \\
\text { discrimination }\end{array}$ & & $-0.148(0.419)$ & & & & $0.525(0.485)$ & & \\
\hline L1.tensions & & & $0.942^{*}(0.568)$ & & & & $1.102(0.826)$ & \\
\hline $\begin{array}{l}\text { L1. overlap \& } \\
\text { tensions }\end{array}$ & & & & $0.849^{*}(0.441)$ & & & & $2.239^{* * *}(0.781)$ \\
\hline L1.log population & $0.183(0.158)$ & $0.134(0.144)$ & $0.0203(0.150)$ & $0.0266(0.149)$ & $0.122(0.301)$ & $0.113(0.186)$ & $-0.0461(0.278)$ & $0.00750(0.226)$ \\
\hline L1.gdp growth & $0.0221(0.0135)$ & $0.0213(0.0139)$ & $0.0460(0.0315)$ & $0.0424(0.0310)$ & $0.0151(0.0108)$ & $0.0158(0.0111)$ & $0.0214(0.0321)$ & $0.0263(0.0321)$ \\
\hline L1.log gdppc & $-0.376^{* *}(0.188)$ & $-0.279(0.195)$ & $-0.444(0.304)$ & $-0.506(0.317)$ & $-0.359(0.308)$ & $-0.180(0.225)$ & $-0.315(0.433)$ & $-0.345(0.395)$ \\
\hline L1.durable & $-0.0148(0.0165)$ & $-0.0212(0.0173)$ & $-0.0158(0.0286)$ & $-0.0187(0.0299)$ & $-0.0378(0.0298)$ & $-0.0479^{*}(0.0278)$ & $-0.0888(0.0653)$ & $-0.0853(0.0637)$ \\
\hline L1.polity2 & $0.0340(0.0309)$ & $0.0209(0.0291)$ & $0.0472(0.0383)$ & $0.0527(0.0381)$ & $0.0632(0.0430)$ & $0.0294(0.0391)$ & $0.0741(0.0525)$ & $0.0577(0.0486)$ \\
\hline L1.Imtnest_i & $0.189(0.115)$ & $0.0826(0.0995)$ & $0.0328(0.125)$ & $0.0556(0.123)$ & $0.208(0.220)$ & $0.0125(0.152)$ & $0.160(0.252)$ & $0.0523(0.200)$ \\
\hline Peace years & $-0.0987^{* * *}(0.0334)$ & $-0.119^{* * * *}(0.0352)$ & $-0.101^{* *}(0.0428)$ & $-0.0955^{* *}(0.0453)$ & $-0.0788(0.0482)$ & $-0.118^{* x}(0.0526)$ & $-0.0540(0.0528)$ & $-0.0597(0.0564)$ \\
\hline _cons & $-3.469(2.573)$ & $-2.533(2.647)$ & $-1.086(2.873)$ & $-0.229(2.924)$ & $-4.653(3.708)$ & $-3.274(3.010)$ & $-3.689(3.437)$ & $-2.203(3.236)$ \\
\hline $\bar{N}$ & 750 & 750 & 555 & 555 & 750 & 750 & 555 & 555 \\
\hline Pseudo $R^{2}$ & 0.089 & 0.067 & 0.106 & 0.104 & 0.148 & 0.080 & 0.196 & 0.176 \\
\hline
\end{tabular}

Robust standard errors in parentheses; ${ }^{*} p<.10,{ }^{* *} p<.05,{ }^{* * *} p<.01,{ }^{* * * *} p<.001$.

Source: authors' compilation. 
Table 6. Summary of effects of religious variables

\begin{tabular}{|c|c|c|c|c|}
\hline \multirow{2}{*}{ Structural variables } & \multicolumn{2}{|c|}{$\begin{array}{l}\text { Armed conflict } \\
\text { onset }\end{array}$} & \multicolumn{2}{|c|}{$\begin{array}{c}\text { Religious armed conflict } \\
\text { onset }\end{array}$} \\
\hline & & & & \\
\hline L1.fractionalization & $-2.037^{* * *}$ & $(0.13)$ & $-1.747^{*}$ & $(0.17)$ \\
\hline L1.polarization & $-1.776^{* * *}$ & $(0.17)$ & -0.493 & $(0.61)$ \\
\hline L1.religious-ethnic overlap & $0.633^{*}$ & $(1.88)$ & $2.412^{* * * *}$ & (11.16) \\
\hline L1.dominance islam & $0.737^{* *}$ & $(2.09)$ & 0.397 & (1.49) \\
\hline \multicolumn{5}{|l|}{ Variables of 'politicized' religion } \\
\hline L1.tensions & $0.954^{*}$ & $(2.60)$ & 0.878 & (2.41) \\
\hline L1.discrimination & -0.472 & $(0.62)$ & 0.199 & $(1.22)$ \\
\hline L1.calls for violence & -0.461 & $(0.63)$ & 0.0504 & $(1.05)$ \\
\hline \multicolumn{5}{|l|}{ Combined variables } \\
\hline $\begin{array}{l}\text { L1.polarization75 \& } \\
\text { discrimination }\end{array}$ & -0.0639 & $(0.94)$ & $0.964^{*}$ & (2.62) \\
\hline L1.polarization75 \& tensions & -0.2981 & $(0.74)$ & $1.0564^{* *}$ & (2.86) \\
\hline L1.dominance \& discrimination & -0.787 & $(0.46)$ & -1.286 & $(0.28)$ \\
\hline L1.dominance \& tensions & $0.927^{* *}$ & $(2.53)$ & -0.285 & $(0.75)$ \\
\hline L1.overlap \& discrimination & -0.148 & $(0.86)$ & 0.525 & (1.69) \\
\hline L1.overlap \& tensions & $0.849^{*}$ & $(2.34)$ & $2.239^{* * *}$ & $(9.39)$ \\
\hline
\end{tabular}

Notes: Odds ratios in parentheses ${ }^{*} p<.10,{ }^{* *} p<.05,{ }^{* * *} p<.01,{ }^{* * * *} p<.001$ (significant relations bold), Source: authors' compilation (for details see also Tables 1-5 and Appendix, all other variables not significant).

armed conflict in general as predicted by Hypothesis 2 (see Table 6). An exception is the overlap of religious and ethnic boundaries which is significant for both types of conflict but stronger for religious conflict onset. More importantly, however, the best models and variables for the two types of conflict differ ${ }^{64}$ Religious tensions and dominance (also in combination) mainly impact armed conflict in general, while religious polarization is only a positive predictor for religious armed conflict—and this holds true only when it is combined with either discrimination or religious tensions.

Besides the above mentioned empirical contribution, our results also have implications for the general debate on the link between religion and conflict which we discussed at the beginning of the paper. In terms of theory, the results are far from being incompatible with the mobilization hypothesis, though they generally fail to demonstrate that mobilization always needs both conflict-prone structures and actual politicization. In general, we have evidence that particular structures are conflict-prone (identity overlaps \& dominance), at least one (polarization) only if combined with variables indicating behavioral dimension and/or mobilization (discrimination and tensions). Generally, however, the evidence for the role of variables indicating politicization, especially verbal calls for violence by religious actors, is less substantial than expected. Besides issues of reliability - calls for violence may have been inconsistently recorded in the database-one theoretical conclusion may be that socio-psychological intergroup processes are more important than religious ideas and their use by leaders. According to this view, which should be investigated 
in more detail in the future, mobilization might be mainly a function of conflict-prone structures and not so much the result of the combination with actual politicization. An alternative, at least partial, solution to this puzzle stems from the findings on the substantial role of overlapping ethnic and religious identities. Many conflicts in which the warring factions differ by religious identity are at the same time ethnic conflicts, and the politicization and mobilization may be found in the realm of ethnicity. ${ }^{65}$ Consider the case of Côte d'Ivoire: religious differences add to the ethno-regional differences between North and South, and they were mobilized in the field of ethnicity rather than religion. ${ }^{66}$ In any case, the exact processes of mobilization should be traced more thoroughly in the future, probably through more qualitative research designs rather than large $N$ studies.

\section{Conclusion}

The religiously diverse societies south of the Sahara and the religious overtones in a number of African conflicts show the importance of conducting empirical studies such as the one presented here. Most global quantitative studies limit their analysis to demographic variables, and systematic studies on Africa are completely absent. Case studies study the religion-conflict link more closely but focus on a limited number of cases. The questions thus remain of whether religious factors significantly impact the onset of armed conflict in Africa, and what may explain the religious overtones in some of these conflicts.

The utility of the unique RSSA database is demonstrated by the results of a causal analysis employing logit regressions. Though religion does not explain everything, findings lend empirical support to the idea that religious variables substantially impact (religious) armed conflict in Africa.

Theoretically, results are roughly in line with the mobilization hypothesis which suggests that certain demographic structures are conflict-prone but have to be politicized in order to trigger violent conflict. Our findings emphasize the role of conflict-prone religious structures. Religious and ethnic identity overlaps are the most significant and strongest predictors for both armed and religious armed conflict, while dominance only counts for armed conflict. Polarization only proves significant if combined with variables exceeding pure structures and containing an element of politicization (discrimination and tension). Particularly, the strong role of overlapping ethnic and religious identities, alone and in combination, calls for future research. This finding suggests that religious armed conflicts are often at the same time ethnic conflicts, and mobilization of identities may mainly work through "ethnic channels." Future research should therefore engage in a more in-depth investigation of the interaction of ethnicity and religion in conflicts and politics general.

Our findings have implications for the resolution of conflict. Although an extensive discussion of these implications is beyond the scope of this paper, decision-makers and practitioners should maintain religion, and particularly, interreligious tensions on the radar of early warning. Advancing inter-religious dialogue is an obvious implication for conflict prevention in this context.

Religious extremism in Africa is also a subject of interest, as recent developments in Nigeria and Somalia and the activities of Al-Qaeda in the Islamic Maghreb (AQMI) within the Sahelian countries show. Given space constraints and the apparently higher relevance of the identity dimension we have concentrated on the latter in 
this paper. However, religious extremism certainly poses a problem in Africa and it should be studied with greater care in the future.

[Superscripted numbering in endnotes below should be replaced with non-superscripted numbering as follows: 1. 2. 3., etc.]

\section{Notes}

1. If not indicated otherwise, "Africa" denotes the 48 countries of "sub-Saharan Africa" (that is, excluding North Africa).

2. Jeffrey Dixon, "What Causes Civil Wars? Integrating Quantitative Research Findings," International Studies Review 11, no. 4 (2009): 707-735; Håvard Hegre and Nicholas Sambanis, "Sensitivity Analysis of Empirical Results on Civil War Onset," Journal of Conflict Resolution 50, no. 4 (2006): 508-535; James Fearon and David Laitin, "Ethnicity, Insurgency, and Civil War," American Political Science Review 97, no. 1 (2003): 75-90; Paul Collier and Nicholas Sambanis (eds.), Understanding Civil War: Evidence and Analysis, 1, Africa (Washington, DC: World Bank, 2005); Ibrahim Elbadawi and Nicolas Sambanis, "Why are There So Many Civil Wars in Africa? Understanding and Preventing Violent Conflict," Journal of African Economics 9, no. 3 (2000): 224-269.

3. We define "armed conflict" according to the definition by UCDP/PRIO. Such a conflict is a contested incompatibility that has created at least 25 battle-related deaths (see Table A1). As religious armed conflict we conceptualize all such conflicts in which either the conflict parties significantly differ by their religious affiliation (e.g., in Côte d'Ivoire between Muslims and Christians) or in which the warring factions have an incompatibility regarding religious ideas such as the role of religion in the state. The latter regularly includes religious extremism (e.g., the conflict in Northern Nigeria; see also "data and empirical strategy" and Table A1).

4. According to findings by Basedau et al., in 23 out of 48 sub-Saharan countries religion is connected to conflict in one form or other. See Matthias Basedau, Georg Strüver, and Johannes Vüllers, "Cutting Bread or Cutting Throats? - Findings from a New Database on Religion, Violence and Peace in Sub-Saharan Africa, 1990 to 2008," GIGA Working Papers, no. 159 (Hamburg: GIGA German Institute of Global and Area Studies, 2011). This is much higher than the religious conflict prevalence found by Svensson and Croissant et al. See Isak Svensson, "Fighting with Faith: Religion and Conflict Resolution in Civil Wars," Journal of Conflict Resolution 51, no. 6 (2007): 930-949; and Aurel Croissant, Uwe Wagschal, Nicolas Schwank, and Christoph Trinn, Kultur und Konflikt in globaler Perspektive. Die kulturellen Dimensionen des Konfliktgeschehens 1945-2007 [Culture and Conflict from a Global Perspective. The Cultural Dimensions of Conflict, 1945-2007]. (Gütersloh: Verlag BertelsmannStiftung, 2010).

5. Pew Forum on Religion \& Public Life (2010), Tolerance and Tension: Islam and Christianity in Sub-Saharan Africa, http://pewforum.org/uploadedFiles/Topics/Belief_and_ Practices/sub-saharan-africa-full-report.pdf (accessed August 10, 2010); Stephen Ellis and Gerrie Ter Haar, "Religion and Politics: Taking African Epistemologies Seriously," Journal of Modern African Studies 45, no. 3 (2007): 385-401.

6. E.g. Samuel P. Huntington, The Clash of Civilizations and the Remaking of World Order (New York: Simon \& Schuster, 1996); Mark Juergensmeyer, Global Rebellion: Religious Challenges to the Secular State from Christian Militias to al Qaeda (Berkeley: University of California Press, 2008).

7. This article focuses on the religion-conflict link. Looking at the peace dimension is certainly commendable but beyond the scope of this paper. See Scott Appleby, The Ambivalence of the Sacred: Religion, Violence and Reconciliation (Lanham, MD: Rowman \& Littlefield, 2000); Daniel Philpott, "Explaining the Political Ambivalence of Religion," American Political Science Review 101, no. 3 (2007): 505-525.

8. Matthias Basedau and Alexander De Juan, "The Ambivalence of the Sacred in Africa: The Impact of Religion in Sub-Saharan Civil Conflicts," GIGA Working Papers, no. 70 (Hamburg: GIGA German Institute of Global and Area Studies, 2008).

9. As argued by, for instance, Gerrie Ter Haar, "Religion: Source of Conflict or Resource for Peace?," in Gerrie Ter Harr and James Busuttil (eds.), Bridge or Barrier: Religion, Violence, and Visions for Peace (Leiden: Brill, 2005): 3-34. 
10. Matthias Basedau, "Religion und Gewaltkonflikt im subsaharischen Afrika. Zur Rolle religiöser Faktoren in Benin und der Elfenbeinküste" [Religion and Violent Conflict in Sub-Saharan Africa. On the Role of Religious Factors in Benin and Ivory Coast] in Margit Bussmann, Andreas Hasenclever, and Gerald Schneider (eds.), Identität, Institutionen und Ökonomie. Ursachen innenpolitischer Gewalt [Identity, Institutions, and Economy. Causes of Intrastate Violence] PVS-Sonderheft 43 (Wiesbaden: VS Verlag für Sozialwissenschaften, 2009): 150-177; Kristian Berg Harpviken and Hanne Eggen Røislien, "Faithful Brokers? Potentials and Pitfalls of Religion in Peacemaking," Conflict Resolution Quarterly 25, no. 3 (2008): 351-373.

11. Jeffrey Seul, "Ours is the Way of God: Religion, Identity, and Intergroup Conflict," Journal of Peace Research 36, no. 5 (1999): 565; Frances Stewart, "Religion versus Ethnicity as a Source of Mobilisation: Are There Differences?," MICROCON Research Working Paper, 18 (Brighton: Institute of Development Studies at the University of Sussex, 2009).

12. E.g. Isak Svensson and Emily Harding, "How Holy Wars End: Exploring the Termination Patterns of Conflict with Religious Dimensions in Asia," Terrorism and Political Violence 23, no. 2 (2011): 135; Michael C. Horowitz, "Long Time Going: Religion and the Duration of Crusading," International Security 34, no. 2 (2009): 167-172.

13. E.g. Paul N. Anderson, "Religion and Violence: From Pawn to Scapegoat," in Harold Ellens (ed.), The Destructive Power of Religion: Violence in Judaism, Christianity, and Islam (Westport, CT: Praeger, 2004): 265-283; Monica Duffy Toft, "Getting Religion? The Puzzling Case of Islam and Civil War," International Security 31, no. 4 (2007): 97-131; Isak Svensson, "Fighting with Faith" (see note 4 above).

14. James Fearon and David Laitin, "Violence and the Social Construction of Ethnic Identity," International Organization 54, no. 4 (2000): 845-877; Alexander De Juan, "A Pact with the Devil? - Elite Alliances as Bases of Violent Religious Conflicts," Studies in Conflict and Terrorism 31, no. 12 (2009): 1120-1135.

15. Toft argues it the other way around: political elites will tender religious bids, if religious legitimacy seems to be rational to secure their own survival (Monica Duffy Toft, "Getting Religion?" 102-107; see note 13). This also emphasizes the role of political leaders for the process of religious charging of a conflict. Another approach argues that successful mobilization requires that both sides - conflict party and religious actor-must have interest in it (Alexander De Juan, "A Pact with the Devil?" see note 14 above). But in both approaches it is necessary that religious leaders convince their believers of their religious interpretationswhich is likelier under specific (non-)religious conditions such as credibility of religious leaders or problematic inter-religious relations.

16. E.g. Nikki R. Keddie, "The New Religious Politics: Where, When, and Why Do 'Fundamentalisms' appear," Comparative Studies in Society and History 40, no. 4 (1998): 696-723; Andreas Hasenclever and Alexander De Juan, "Grasping the Impact of Religious Traditions on Political Conflicts: Empirical Findings and Theoretical Perspectives," Friedens-Warte: Journal of International Peace and Organization 82, no. 2-3 (2007): 21-24.

17. Samuel P. Huntington, The Clash of Civilizations (see note 6 above); Andreas Hasenclever and Volker Rittberger, "Does Religion Make a Difference? Theoretical Approaches to the Impact of Faith on Political Conflict," in Pavlos Hatzopolous and Fabio Petito (eds.), Religion in International Relations: The Return from Exile (New York: Palgrave Macmillan, 2003): $109-110$.

18. E.g. Bruce M. Russet, John R. Oneal, and Michaelene Cox, "Clash of Civilizations, or Realism and Liberalism Déjà Vu? Some Evidence," Journal of Peace Research 37, no. 5 (2000): 583-608; Andrej Tusicisny, "Civilizational Conflicts: More Frequent, Longer, and Bloodier?," Journal of Peace Research 41, no. 4 (2004): 485-498.

19. E.g. Aurel Croissant, Uwe Wagschal, Nicolas Schwank, and Uwe Trinn, "Kultur und Konflik," (see note 4 above); José G. Montalvo and Marta Reynal-Querol, "Ethnic Polarization, Potential Conflict and Civil War," American Economic Review 95, no. 3 (2005): 796-816; James Fearon and David Laitin, "Ethnicity, Insurgency, and Civil War" (see note 2 above); Tanja Ellingsen, "Colourful Community or Ethnic Witches' Brew? Multiethnicity and Domestic Conflict During and After the Cold War," Journal of Conflict Resolution 44, no. 2 (2000): 228-249.

20. Michael C. Horowitz, "Long Time Going" (see note 12 above), 167-172; Isak Svensson, "Fighting with Faith" (see note 4 above); Monica Duffy Toft, "Getting Religion?" 
(see note 13 above); Susanna Pearce, "Religious Rage: A Quantitative Analysis of the Intensity of Religious Conflicts," Terrorism and Political Violence 17, no. 3 (2005): 333-352; Tanja Ellingsen, "Toward a Revival of Religion and Religious Clashes?," Terrorism and Political Violence 17, no. 3 (2005): 305-332.

21. Asaf Moghadam, A Global Resurgence of Religion?, Working Paper 03-03 (Weatherhead Center for International Affairs: Harvard University, 2003); Jonathan Fox, "The Increasing Role of Religion in State Failure: 1960 to 2004," Terrorism and Political Violence 19 , no. 3 (2007): 395-414.

22. Quintan Wiktorowicz, "Framing Jihad: Intramovement Framing Contest and al-Qaeda's Struggle for Sacred Authority," International Review of Social History 49 (2004): 159-177; Jonathan Fox, "The Influence of Religious Legitimacy on Grievance Formation by Ethno-Religious Minorities," Journal of Peace Research 36, no. 3 (1999): 289-307.

23. Matthias Basedau and Alexander De Juan, "The Ambivalence of the Sacred in Africa"' (see note 8 above), 6 .

24. Pew Forum on Religion \& Public Life (2010), Tolerance and Tension (see note 5 above); Stephen Ellis and Gerrie Ter Haar, "Religion and Politics" (see note 5 above); John F. McCauley and Emmanuel Gyimah-Boadi, Religious Faith and Democracy: Evidence from the Afrobarometer Surveys, Afrobarometer Working Papers 113 (Ghana: Afrobarometer, 2009).

25. Matthias Basedau, Georg Strüver, and Johannes Vüllers, "Cutting Bread or Cutting Throats " (see note 4 above).

26. Paul Collier and Nicholas Sambanis (eds.), Understanding Civil War (see note 2 above); Ibrahim Elbadawi and Nicolas Sambanis, "Why are There So Many Civil Wars in Africa?" (see note 2 above).

27. Paul Collier and Anke Hoeffler, "On the Incidence of Civil War in Africa," Journal of Conflict Resolution 46, no. 1 (20002): 13-28.

28. Jeffrey Haynes, "Religion in African Civil Wars," in Manfred Brocker and Mathias Hildebrandt (eds.), Unfriedliche Religionen? Das politische Gewalt- und Konfliktpotenzial von Religionen [Violent Religion? The Potential of Religions for Political Violence and Conflict] (Wiesbaden: VS Verlag für Sozialwissenschaften, 2005): 277-294.

29. Matthias Basedau and Johannes Vüllers, "Religion als Konfliktfaktor? Eine systematische Erhebung religiöser Gewaltdimensionen im subsaharischen Afrika" [Religion as Conflict Risk? A Systematic Overview on the Violent Dimensions of Religion in Sub-Saharan Africa], Friedens-Warte, Journal of International Peace and Organization 83, nos. 1-2 (2010): $39-62$.

30. See also Frances Stewart, "Religion versus" (see note 11 above).

31. E.g. Johannes Harnischfeger, Demokratisierung und Islamisches Recht. Der Scharia-Konflikt in Nigeria [Democratization and Islamic Law: The Sharia-Conflict in Nigeria] (Frankfurt: Campus Verlag, 2006); Roy Love, "Religion, Ideology and Conflict in Africa," Review of African Political Economy 33, no. 110 (2006): 619-634.

32. Matthias Basedau and Johannes Vüllers, "Religion als Konfliktfaktor?" (see note 29 above), 53-55.

33. Marta Reynal-Querol, "Ethnicity, Political Systems, and Civil Wars," Journal of Conflict Resolution 46, no. 1 (2002): 29-54; Montalvo and Reynal-Querol, "Ethnic Polarization, Potential Conflict and Civil War" (see note 19 above); Tanja Ellingsen, "Colourful Community or Ethnic Witches' Brew?" (see note 19 above).

34. Frances Stewart, "Religion versus Ethnicity as a Source of Mobilisation" (see note 11 above).

35. Andrew J. Slack and Roy R. Doyon, "Population Dynamics and Susceptibility for Ethnic Conflict: The Case of Bosnia and Herzegovina," Journal of Peace Research 38, no. 2 (2001): 139-161.

36. E.g. Jeffrey Seul, "Ours is the Way of God" (see note 11 above)

37. Ted R. Gurr, Peoples versus States: Minorities at Risk in the New Century (Washington D.C.: United States Institute of Peace, 2000); Jonathan Fox, Religion, Civilization, and Civil War: 1945 Through the New Millennium (Oxford: Lexington, 2004a): 90-93.

38. E.g. Monica Duffy Toft, "Getting Religion?" (see note 13 above), 97; Isak Svensson, "Fighting with Faith" (see note 4 above), 936-937.

39. Eritrea became an independent state in 1993 (before: 47 states). 
40. Usually, these are new conflicts. However, we also count new episodes of armed conflicts as onset if the conflict remained under 25 battle deaths for at least one year. See Nils Petter Gleditsch, Peter Wallensteen, Mikael Eriksson, Margareta Sollenberg, and Håvard Strand, "Armed Conflict 1946-2001: A New Dataset," Journal of Peace Research 39, no. 5 (2002): 615-637; Lotta Harbom and Peter Wallensteen, "Armed Conflict, 1946-2008," Journal of Peace Research 46, No. 4 (2009): 577-587.

41. Following the suggestion made by Hegre and Sambanis, ongoing conflict years are coded as $0 \mathrm{~s}$ instead of dropping them from the sample, as multiple conflicts happening in the same country are not uncommon (Håvard Hegre and Nicholas Sambanis, "Sensitivity Analysis of Empirical Results on Civil War Onset" (see note 2 above), 523).

42. Alberto Alessina, Arnaud Devleeschauwer, William Easterly, Sergio Kurlat, and Romain Wacziarg, "Fractionalization," Journal of Economic Growth 8, no. 2 (2003): 155-194.

43. We have recalculated the values for all sub-Saharan countries on the basis of data provided by the World Christian Database; see José G. Montalvo and Marta Reynal-Querol, "Ethnic Polarization, Potential Conflict and Civil War" (see note 19 above).

44. Please note that this kind of parallel identity differs from differences in religious identities between the conflict parties. Here, we deal with overlaps of religious and ethnic/social identities in society, but not with overlaps of religious identities and the support base/members of the conflict parties.

45. The coding is based on data on the inter-religious structure provided by the World Christian Database. Due to the fact that the share of African Traditionalists (ATR) does not exceed $50.5 \%$ in any country, no variable on ATR dominance is coded (see also Table A2 in the Annex).

46. Jonathan Fox, The Religion and State Project, Version I (2004b), http:// www-thearda.com/ras/downloads (accessed December 9, 2010).

47. In total, we coded six "combined variables": polarization 75 \& discrimination, polarization 75 \& tensions, dominance \& discrimination, dominance \& tensions, overlap \& discrimination, overlap \& tensions. Polarization75 is a dichotomous variable indicating whether a state is considered religiously polarized or not. It equals " 1 " if the country's religious polarization value exceeds the sample's 75th percentile. An overview of all the variables employed in this study is given in Table A1 of the Annex. Table A2 reports descriptive statistics.

48. Håvard Hegre and Nicholas Sambanis, "Sensitivity Analysis of Empirical Results on Civil War Onset" (see note 2 above); Jeffrey Dixon, "What Causes Civil Wars?" (see note 2 above).

49. Although oil exports are frequently mentioned as a robust correlate of civil war, we do not employ it as a control for three reasons. First, we had to limit the number of controls. Second, according to the sensitivity analysis by Hegre and Sambanis, oil does not belong to the highly robust correlates of civil war (which we use; Håvard Hegre and Nicholas Sambanis, "Sensitivity Analysis of Empirical Results on Civil War Onset" (see note 2 above, 533). Finally, our own pre-testing did not find oil to be robustly connected to civil war in Africa.

50. See Keith Jaggers and Monty G. Marshall, Polity 4 Project - Political Regime Characteristics and Transitions, 1800-2007, Dataset Users' Manual, http://www.systemicpeace. org/inscr/p4manualv2007.pdf (accessed February 18, 2009).

51. From Håvard Hegre and Nicholas Sambanis, "Sensitivity Analysis of Empirical Results on Civil War Onset" (see note 2 above).

52. Nathaniel Beck, Jonathan N. Katz, and Richard Tucker, "Taking Time Seriously: Time-Series-Cross-Section Analysis with a Binary Dependent Variable," American Journal of Political Science 42, no. 4 (1998): 1260-1288.

53. Likelihood Ratio Tests of the reported specification against several different nested models revealed that the applied full models have a proper specification. In addition, a stepwise inclusion of all independent variables as well as the variance inflated factor (VIF) indicated that the reported findings are unlikely to be driven by multi-collinearity.

54. In addition to the logit estimations, "rare-event logit models" as suggested by King and Zeng were equally performed for all models presented in this paper. The authors show that when binary dependent variables measure the occurrence of "rare events," standard logit or probit estimations may produce biased coefficients (Gary King and Langche Zeng, "Explaining Rare Events in International Relations," International Organization 55, no. 3 (2001): 693-715). 
55. Interestingly, the overlap of religion and social stratum (religious-social overlap) does not produce significant results.

56. Joan Esteban and Debraj Ray, "Polarization, Fractionalization and Conflict," Journal of Peace Research 45, no. 2 (2008): 163-182. 1985).

57. Donald Horowitz, Ethnic Groups in Conflict (Berkeley: University of California Press,

58. Paul Collier and Anke Hoeffler, "On Economic Causes of Civil War," Oxford Economic Papers 50 (Oxford University Press, 1998): 563-573; Tanja Ellingsen, "Colourful Community or Ethnic Witches' Brew?" (see note 19 above).

59. Paul Collier and Anke Hoeffler, "Greed and Grievance in Civil War," Oxford Economic Papers 56, no. 4 (2004): 563-595.

60. Further variables on the religious structure such as change of (religious) demography, the inter-religious structure (islam, christ, atr), and overlap of religious and regional boundaries (religious-regional overlap, religious-social overlap) — not reported here due to space constraints-were considered by our estimations. The majority does not reach statistical significance. Noteworthy exceptions are parallel religious and regional boundaries increasing the risk of religious conflict (significant at the 10\% level). ATR percentage share show negative and significant results as well and, expressed in odds ratio, reduce the risk of armed conflict and religious armed conflict by $5 \%$ and $6 \%$, respectively.

61. We further tested the effect of religious discrimination against minority religions (minority discrimination), and escalation by religious actors and/or institutions (religious calls for violence). None of them reached statistical significance.

62. We further tested the combined effects of several structural variables (such as fractionalization and demographic change) with other politicized variables (such as discrimination, tensions, and calls for violence). None of them reached statistical significance and are not reported due to space constraints.

63. We should also keep in mind that the explained variance of the models is relatively low with Pseudo $R^{2}$ s often remaining below 0.1 .

64. For religious conflict onset (2), an armed conflict with religious incompatibility, the following variables proved significant: religious-ethnic overlap (positive, 5\% level), demographic change (negative, 10\%), tensions (positive, 1\%), religious calls for violence (positive, $5 \%$ ). Positive significant results were also returned for the following combinations (all at the $5 \%$ level): tensions \& religious-ethnic overlap, tensions \& polarization, polarization $\&$ discrimination, polarization \& religious calls for violence.

65. For religious conflict onset (2), an armed conflict with religious incompatibility, the following variables proved significant: religious-ethnic overlap (positive, 5\% level), demographic change (negative, $10 \%$ ), tensions (positive, 1\%), religious calls for violence (positive, $5 \%$ ). Positive significant results were also returned for the following combinations (all at the $5 \%$ level): tensions \& religious-ethnic overlap, tensions \& polarization, polarization \& discrimination, polarization \& religious calls for violence.

66. Ragnhild Nordås, Identity Polarization and Conflict: State building in Côte d'Ivoire and Ghana, Paper prepared for the Conference Polarization and Conflict, Gaillac 7-9 June 2007. 


\section{APPENDIX}

Table A1. Variable definitions and data sources

\begin{tabular}{|c|c|c|}
\hline Variable & Definition & Source \\
\hline Conflict onset & $\begin{array}{l}\text { Armed conflict onset ( }>25 \text { battle } \\
\text { deaths) according to UCDP/ } \\
\text { PRIO onset data (v. 4-2010), } \\
\text { coded } 1 \text { if at least one onset } \\
\text { occurred in a given year and } \\
0 \text { otherwise }\end{array}$ & $\begin{array}{l}\text { Harbom/Wallensteen 2009; } \\
\text { Gleditsch et al. } 2002\end{array}$ \\
\hline $\begin{array}{l}\text { Religious conflict } \\
\text { onset }\end{array}$ & $\begin{array}{l}\text { Armed conflict onset with conflict } \\
\text { parties differing by religious } \\
\text { affiliation, coded } 1 \text { if at least } \\
\text { one onset occurred in a given } \\
\text { year and } 0 \text { otherwise }\end{array}$ & $\begin{array}{l}\text { Own coding on the basis of } \\
\text { UCDP/PRIO (RSSA) }\end{array}$ \\
\hline $\begin{array}{l}\text { Religious conflict } \\
\text { onset (2) }\end{array}$ & $\begin{array}{l}\text { Armed conflict onset with } \\
\text { religious incompatibility, coded } \\
1 \text { if at least one onset occurred } \\
\text { in a given year and } 0 \text { otherwise }\end{array}$ & $\begin{array}{l}\text { Own coding on the basis of } \\
\text { UCDP/PRIO (RSSA) }\end{array}$ \\
\hline $\begin{array}{l}\text { Demographic } \\
\text { change }\end{array}$ & $\begin{array}{l}\text { Coded } 1 \text { if moderate or strong } \\
\text { changes in religious } \\
\text { demography (relative size of } \\
\text { groups) occurred and } 0 \\
\text { otherwise }\end{array}$ & Own coding (RSSA) \\
\hline Fractionalization & Religious fractionalization index & $\begin{array}{l}\text { Alesina et al. 2003, missing years } \\
\text { imputed }\end{array}$ \\
\hline Polarization & $\begin{array}{l}\text { Polarization index of } \\
\text { inter-religious structure } \\
\text { (Christians, Muslims, African } \\
\text { Traditional) }\end{array}$ & $\begin{array}{l}\text { Own coding (data: World } \\
\text { Christian Database) }\end{array}$ \\
\hline Polarization 75 & Third quartile of polarization & Own coding \\
\hline $\begin{array}{l}\text { Religious-ethnic } \\
\text { overlap }\end{array}$ & $\begin{array}{l}\text { Coded } 1 \text { if religious identities } \\
\text { overlap at least partially with } \\
\text { ethnic boundaries and } 0 \\
\text { otherwise }\end{array}$ & Own coding (RSSA) \\
\hline $\begin{array}{l}\text { Religious-regional } \\
\text { overlap }\end{array}$ & $\begin{array}{l}\text { Coded } 1 \text { if religious identities } \\
\text { overlap at least partially with } \\
\text { regional boundaries and } 0 \\
\text { otherwise }\end{array}$ & Own coding (RSSA) \\
\hline $\begin{array}{l}\text { Religious-social } \\
\text { overlap }\end{array}$ & $\begin{array}{l}\text { Coded } 1 \text { if religious identities } \\
\text { overlap at least partially with } \\
\text { social boundaries and } 0 \\
\text { otherwise }\end{array}$ & Own coding (RSSA) \\
\hline ATR & $\begin{array}{l}\text { Inter-religious structure, } \\
\text { percentage share of adherents to } \\
\text { African Traditional Religions }\end{array}$ & $\begin{array}{l}\text { Own coding (data: World } \\
\text { Christian Database) }\end{array}$ \\
\hline Islam & $\begin{array}{l}\text { Inter-religious structure, } \\
\text { percentage share of adherents to } \\
\text { Islam }\end{array}$ & $\begin{array}{l}\text { Own coding (data: World } \\
\text { Christian Database) }\end{array}$ \\
\hline
\end{tabular}


Table A1. Continued

\begin{tabular}{|c|c|c|}
\hline Variable & Definition & Source \\
\hline Christ & $\begin{array}{l}\text { Inter-religious structure, } \\
\text { percentage share of adherents to } \\
\text { the Christian church }\end{array}$ & $\begin{array}{l}\text { Own coding (data: World } \\
\text { Christian Database) }\end{array}$ \\
\hline Dominance Christ & $\begin{array}{l}\text { Coded } 1 \text { if the percentage share of } \\
\text { Christians exceeds } 60 \% \text { and } 0 \\
\text { otherwise }\end{array}$ & $\begin{array}{l}\text { Own coding (data: World } \\
\text { Christian Database) }\end{array}$ \\
\hline Dominance Islam & $\begin{array}{l}\text { Coded } 1 \text { if the percentage share of } \\
\text { Muslims exceeds } 60 \% \text { and } 0 \\
\text { otherwise }\end{array}$ & $\begin{array}{l}\text { Own coding (data: World } \\
\text { Christian Database) }\end{array}$ \\
\hline Dominance & $\begin{array}{l}\text { Coded } 1 \text { if the percentage share of } \\
\text { Muslims or Christians exceeds } \\
60 \% \text { and } 0 \text { otherwise }\end{array}$ & $\begin{array}{l}\text { Own coding (data: World } \\
\text { Christian Database) }\end{array}$ \\
\hline Tensions & $\begin{array}{l}\text { Inter-religious relations (moderate } \\
\text { or strong tension present) }\end{array}$ & Own coding (RSSA) \\
\hline Discrimination & $\begin{array}{l}\text { Coded } 1 \text { if a religious community } \\
\text { feels discriminated and } 0 \\
\text { otherwise }\end{array}$ & Own coding (RSSA) \\
\hline $\begin{array}{l}\text { Minority } \\
\text { discrimination }\end{array}$ & $\begin{array}{l}\text { Coded } 1 \text { if minority religions } \\
\text { arediscrimination and } 0 \\
\text { otherwise }\end{array}$ & $\begin{array}{l}\text { Binary version of variable } m \text { from } \\
\text { Fox } 2004 \text { (own coding from } \\
\text { 2003-2008) }\end{array}$ \\
\hline Calls for violence & $\begin{array}{l}\text { Coded } 1 \text { if a (secular) conflict } \\
\text { parties/violent actors legitimize } \\
\text { violence referring to religious } \\
\text { ideas/institutions/elites and } 0 \\
\text { otherwise }\end{array}$ & Own coding (RSSA) \\
\hline $\begin{array}{l}\text { Religious calls for } \\
\text { violence }\end{array}$ & $\begin{array}{l}\text { Coded } 1 \text { if escalation by religious } \\
\text { actors/institutions (e.g., } \\
\text { degrading of (adherents of) } \\
\text { other beliefs / non believers, } \\
\text { legitimization or incitement of } \\
\text { violence, and active } \\
\text { engagement) occurred and } 0 \\
\text { otherwise }\end{array}$ & Own coding (RSSA) \\
\hline $\begin{array}{l}\text { Polarization } 75 \& \\
\text { discrimination }\end{array}$ & $\begin{array}{l}\text { Combined effect of polarization } 75 \\
\text { and discrimination, takes a value } \\
\text { of } 1 \text { if both variables are coded } 1 \\
\text { and } 0 \text { otherwise }\end{array}$ & Own coding \\
\hline $\begin{array}{l}\text { Polarization } 75 \& \\
\text { tensions }\end{array}$ & $\begin{array}{l}\text { Combined effect of } \\
\text { polarization_p } 75 \text { and tensions, } \\
\text { takes a value of } 1 \text { if both } \\
\text { variables are coded } 1 \text { and } 0 \\
\text { otherwise }\end{array}$ & Own coding \\
\hline $\begin{array}{l}\text { Dominance \& } \\
\text { discrimination }\end{array}$ & $\begin{array}{l}\text { Combined effect of dominance and } \\
\text { discrimination, takes a value of } 1 \\
\text { if both variables are coded } 1 \text { and } \\
0 \text { otherwise }\end{array}$ & Own coding \\
\hline $\begin{array}{l}\text { Dominance \& } \\
\text { tensions }\end{array}$ & $\begin{array}{l}\text { Combined effect of dominance and } \\
\text { tensions, takes a value of } 1 \text { if } \\
\text { both variables are coded } 1 \text { and } 0 \\
\text { otherwise }\end{array}$ & Own coding \\
\hline
\end{tabular}


Table A1. Continued

\begin{tabular}{|c|c|c|}
\hline Variable & Definition & Source \\
\hline $\begin{array}{l}\text { Overlap \& } \\
\text { discrimination }\end{array}$ & $\begin{array}{l}\text { Combined effect of } \\
\text { religious-ethnic overlap and } \\
\text { discrimination, takes a value of } 1 \\
\text { if both variables are coded } 1 \text { and } \\
0 \text { otherwise }\end{array}$ & Own coding \\
\hline $\begin{array}{r}\text { Overlap \& } \\
\text { tensions }\end{array}$ & $\begin{array}{l}\text { Combined effect of } \\
\text { religious-ethnic overlap and } \\
\text { tensions, takes a value of } 1 \text { if } \\
\text { both variables are coded } 1 \text { and } 0 \\
\text { otherwise }\end{array}$ & Own coding \\
\hline Log population & Log version of total population & $\begin{array}{l}\text { World Bank: African } \\
\text { Development Indicators }\end{array}$ \\
\hline Gdp growth & GDP growth (annual \%) & $\begin{array}{l}\text { World Bank: African } \\
\text { Development Indicators }\end{array}$ \\
\hline Log gdppc & $\begin{array}{l}\text { Log version of GDP per capita } \\
\text { (constant } 2000 \text { USD) }\end{array}$ & $\begin{array}{l}\text { World Bank: African } \\
\text { Development Indicators }\end{array}$ \\
\hline Durable & $\begin{array}{l}\text { Regime durability, years since } \\
\text { most recent regime change }\end{array}$ & Jaggers/Marshall 2009 \\
\hline Polity2 & $\begin{array}{l}\text { Combined polity score from the } \\
\text { Polity IV Project (autocracy and } \\
\text { democracy index) }\end{array}$ & Jaggers/Marshall 2009 \\
\hline lmtnest_I & $\begin{array}{l}\text { Rough terrain (such as } \\
\text { mountainous terrain) }\end{array}$ & $\begin{array}{l}\text { Hegre/Sambanis 2006, missing } \\
\text { years imputed }\end{array}$ \\
\hline Peace years & $\begin{array}{l}\text { Years since last onset of } \\
\text { dependent variable }\end{array}$ & Own coding \\
\hline
\end{tabular}


Table A2. Descriptive statistics

\begin{tabular}{|c|c|c|c|c|c|}
\hline Variable & Observations & Mean & $\begin{array}{l}\text { Standard } \\
\text { deviation }\end{array}$ & Minimum & Maximum \\
\hline Conflict onset & 909 & .0627063 & .2425674 & 0 & 1 \\
\hline Religious conflict onset & 909 & .0286029 & .1667793 & 0 & 1 \\
\hline Religious conflict onset (2) & 909 & .0132013 & .1141989 & 0 & 1 \\
\hline Demographic change & 909 & .1474147 & .354714 & 0 & 1 \\
\hline Fractionalization & 909 & .5023618 & .254891 & .0028 & .8603 \\
\hline Polarization & 909 & .5907701 & .3003853 & .04 & .99 \\
\hline Polarization_p75 & 909 & .310231 & .4628427 & 0 & 1 \\
\hline Religious-ethnic overlap & 909 & .4565457 & .4983824 & 0 & 1 \\
\hline Religious-regional overlap & 909 & .6446645 & .4788784 & 0 & 1 \\
\hline Religious-social overlap & 909 & .1881188 & .3910222 & 0 & 1 \\
\hline ATR & 909 & 15.37625 & 15.18508 & 0 & 50.5 \\
\hline Islam & 909 & 30.29107 & 33.42196 & 0 & 99.09 \\
\hline Christ & 909 & 51.88396 & 34.0492 & .27 & 96.5 \\
\hline Dominance Christ & 909 & .4389439 & .4965313 & 0 & 1 \\
\hline Dominance Islam & 909 & 2090209 & .4068332 & 0 & 1 \\
\hline Dominance & 909 & .6479648 & .4778678 & 0 & 1 \\
\hline Tensions & 713 & .6535764 & .4761641 & 0 & 1 \\
\hline Discrimination & 909 & .2750275 & .446774 & 0 & 1 \\
\hline Minority discrimination & 865 & .5479769 & .4979808 & 0 & 1 \\
\hline Calls for violence & 909 & .0638064 & .2445423 & 0 & 1 \\
\hline Religious calls for violence & 909 & .1320132 & .3386915 & 0 & 1 \\
\hline $\begin{array}{c}\text { Polarization } 75 \text { \& } \\
\text { discrimination }\end{array}$ & 909 & .1276128 & .3338418 & 0 & 1 \\
\hline Polarization $75 \&$ tensions & 713 & .1870187 & .3901412 & 0 & 1 \\
\hline Dominance \& tensions & 713 & .1177118 & .3224439 & 0 & 1 \\
\hline Dominance $\&$ tensions & 713 & .3548387 & .4788003 & 0 & 1 \\
\hline Overlap \& discrimination & 909 & .20022 & .4003852 & 0 & 1 \\
\hline Overlap \& tensions & 713 & .3211781 & .4672568 & 0 & 1 \\
\hline Log population & 909 & 15.47418 & 1.577116 & 11.15625 & 18.8349 \\
\hline Gdp growth & 866 & 3.834566 & 8.185424 & -51.03086 & 106.2798 \\
\hline Log gdppc & 867 & 6.113924 & 1.062943 & 4.130945 & 9.070162 \\
\hline Durable & 852 & 9.673709 & 11.26099 & 0 & 81 \\
\hline Polity2 & 852 & .084507 & 5.463469 & -10 & 10 \\
\hline Imtnest_I & 814 & 1.570248 & 1.407859 & 0 & 4.421247 \\
\hline $\begin{array}{l}\text { Peace years } \\
\text { (conflict onset) }\end{array}$ & 909 & 6.49725 & 5.316134 & 0 & 18 \\
\hline $\begin{array}{l}\text { Peace years (religious } \\
\text { conflict onset) }\end{array}$ & 909 & 7.723872 & 5.532214 & 0 & 18 \\
\hline Peace years & 909 & 8.40154 & 5.548588 & 0 & 18 \\
\hline
\end{tabular}


Table A3. Religious conflicts in Sub-Saharan Africa, 1990-2008

\begin{tabular}{|c|c|c|c|c|}
\hline Country & $\begin{array}{l}\text { Year of } \\
\text { conflict onset } \\
\text { (conflict onset) }\end{array}$ & $\begin{array}{l}\text { Conflict parties } \\
\text { opposing government } \\
\text { forces (Side B) }\end{array}$ & $\begin{array}{l}\text { Religious armed conflict? } \\
\text { Parties differ by religious } \\
\text { affiliation (religious } \\
\text { conflict onset) }\end{array}$ & $\begin{array}{c}\text { Religious armed } \\
\text { conflict? Religious } \\
\text { incompatibility (religious } \\
\text { conflict onset [2]) }\end{array}$ \\
\hline Angola & 1991 & FLEC-R & No & No \\
\hline Angola & 1994 & FLEC-FAC, FLEC-R & No & No \\
\hline Angola & 1996 & FLEC-FAC & No & No \\
\hline Angola & 1998 & UNITA & Yes & No \\
\hline Angola & 2002 & FLEC-FAC, FLEC-R & No & No \\
\hline Angola & 2004 & FLEC-FAC & No & No \\
\hline Angola & 2007 & FLEC-FAC & No & No \\
\hline Burundi & 1991 & Palipehutu & No & No \\
\hline Burundi & 1994 & CNDD & No & No \\
\hline Burundi & 2008 & Palipehutu-FNL & No & No \\
\hline Central African Republic & 2001 & $\begin{array}{l}\text { Military faction (forces of } \\
\text { André Kolingba), Forces } \\
\text { of Francois Bozize }\end{array}$ & No & No \\
\hline Central African Republic & 2006 & UFDR & Yes & No \\
\hline Chad & 1997 & FARF, MDD & Yes & No \\
\hline Chad & 2005 & FUCD & No & No \\
\hline Comoros & 1997 & MPA/Republic of Anjouan & No & No \\
\hline Congo & 1993 & Cobras, Ninjas & Yes & Yes \\
\hline Congo & 1997 & Cobras, Cocoyes & Yes & Yes \\
\hline Congo & 2002 & Ntsiloulous & Yes & Yes \\
\hline Côte d'Ivoire & 2002 & MJP, MPCI, MPIGO, FN & Yes & No \\
\hline $\begin{array}{l}\text { Democratic Republic of the } \\
\text { Congo }\end{array}$ & 1996 & AFDL, MLC, RCD, RCD-ML & No & No \\
\hline $\begin{array}{l}\text { Democratic Republic of the } \\
\text { Congo }\end{array}$ & 2006 & CNDP & No & No \\
\hline
\end{tabular}


Table A3. Continued

\begin{tabular}{|c|c|c|c|c|}
\hline Country & $\begin{array}{c}\text { Year of } \\
\text { conflict onset } \\
\text { (conflict onset) }\end{array}$ & $\begin{array}{l}\text { Conflict parties } \\
\text { opposing government } \\
\text { forces (Side B) }\end{array}$ & $\begin{array}{l}\text { Religious armed conflict? } \\
\text { Parties differ by religious } \\
\text { affiliation (religious } \\
\text { conflict onset) }\end{array}$ & $\begin{array}{c}\text { Religious armed } \\
\text { conflict? Religious } \\
\text { incompatibility (religious } \\
\text { conflict onset [2]) }\end{array}$ \\
\hline $\begin{array}{l}\text { Democratic Republic of the } \\
\text { Congo }\end{array}$ & 2007 & $\mathrm{BDK}$ & Yes & Yes \\
\hline Djibouti & 1991 & FRUD & No & No \\
\hline Djibouti & 1999 & FRUD - AD & No & No \\
\hline Eritrea & 1997 & EIJM - AS & Yes & Yes \\
\hline Eritrea & 1999 & EIJM - AS & Yes & Yes \\
\hline Eritrea & 2003 & EIJM - AS & Yes & Yes \\
\hline Ethiopia & 1994 & OLF; ONLF & Yes & No \\
\hline Ethiopia & 1996 & $\begin{array}{l}\text { ONLF; ARDUF; al-Itahad } \\
\text { al-Islami }\end{array}$ & Yes & Yes \\
\hline Ethiopia & 1998 & Oromiya & Yes & No \\
\hline Ethiopia & 1999 & ONLF; al-Itahad al-Islami & Yes & Yes \\
\hline Ethiopia & 2004 & ONLF & Yes & No \\
\hline Guinea & 2000 & RFDG & No & No \\
\hline Guinea-Bissau & 1998 & $\begin{array}{c}\text { Military Junta for the } \\
\text { Consolidation of Democracy, } \\
\text { Peace and Justice }\end{array}$ & No & No \\
\hline Lesotho & 1998 & Military faction & Yes & No \\
\hline
\end{tabular}




\begin{tabular}{|c|c|c|c|c|}
\hline Liberia & 2000 & LURD, MODEL & Yes & No \\
\hline Mali & 1990 & MPA & No & No \\
\hline Mali & 1994 & FIAA & No & No \\
\hline Mali & 2007 & ATNMC & No & No \\
\hline Niger & 1991 & FLAA & No & No \\
\hline Niger & 1994 & CRA & No & No \\
\hline Niger & 1995 & FDR, FARS & No & No \\
\hline Niger & 1997 & UFRA & No & No \\
\hline Niger & 2007 & MNJ & No & No \\
\hline Nigeria & 2004 & Ahlul Sunnah Jamaa & Yes & Yes \\
\hline Rwanda & 1990 & FDR & No & No \\
\hline Rwanda & 1997 & FDLR & No & No \\
\hline Senegal & 1990 & MFDC & Yes & No \\
\hline Senegal & 1992 & MFDC & Yes & No \\
\hline Senegal & 1995 & MFDC & Yes & No \\
\hline Senegal & 1997 & MFDC & Yes & No \\
\hline Senegal & 2000 & MFDC & Yes & No \\
\hline Senegal & 2003 & MFDC & Yes & No \\
\hline Sierra Leone & 1991 & RUF, AFRC, Kamajors, WSB & No & No \\
\hline Somalia & 2001 & SRRC & No & No \\
\hline Somalia & 2006 & $\begin{array}{l}\text { ARS/UIC, Al-Shabaab, Harakat } \\
\text { Ras Kamboni }\end{array}$ & No & Yes \\
\hline Uganda & 1994 & LRA, ADF, WNBF, UNRF II & Yes & Yes \\
\hline $\begin{array}{l}\text { Total (years with at least one } \\
\text { conflict onset) }\end{array}$ & 57 & & 26 & 12 \\
\hline
\end{tabular}

